2. Федеральный закон от 20.08.2004 № 119-Ф3 (ред. от 07.02.2017) «О государственной защите потерпевших, свидетелей и иных участников уголовного судопроизводства» // Собрание законодательства РФ. 23.08.2004. № 34. Ст. 3534.

3. Федеральный закон от 20.04.1995 № 45-Ф3 (ред. от 30.12.2020) «О государственной защите судей, должностных лиц правоохранительных и контролирующих органов» // Собрание законодательства РФ. 24.04.1995. № 17. Ст. 1455.

4. Брусницын Л.В. Обеспечение безопасности лиц, содействующих уголовному правосудию: российский, зарубежный и международный опыт XX века (процессуальное исследование). - М., 2001.

5. Войников В.В. Тактика обеспечения безопасности в уголовном судопроизводстве: Автореф. дисс. ... канд. юрид. наук. - Калининград, 2002.

6. Макеева Н.В. Понятие и классификация мер безопасности участников уголовного судопроизводства // Вестник Калининградского юридического института МВД России. 2008. № 1 (15).

7. Янин С.А., Тришкина Е.А., Песоцкий А.В. К вопросу о понятии и видах мер обеспечения безопасности в российском уголовном судопроизводстве // Высшее образование. 2017. № 6.

\title{
Селицкий М.В. \\ Система нормативно-правовых актов, регулируюших современные отношения по переходу спортсменов из одного клуба в другой
}

Дальневосточный федеральный университет (Россия, Владивосток)

doi: 10.18411/lj-04-2021-249

\section{Аннотация}

В статье рассматривается система нормативно-правовых актов, регулирующих отношения по переходу спортсменов. Автор приходит к выводу, что рассматриваемые отношения урегулированы только на уровне регламентов профессиональных лиг и федераций, федеральное законодательство в этой части скудно. В связи с этим автором предложены несколько путей решения сложившейся проблемы.

Ключевые слова: спорт, трансфер, переход спортсмена, регламент РФС, регламент КХЛ.

\section{Abstract}

The article examines the system of normative legal acts that regulate the transfer of athletes. The author concludes that the relations under consideration are regulated only at the level of regulations of professional leagues and federations, federal legislation in this part is scarce. In this regard, the author has proposed several ways to solve the problem.

Keywords: sports, transfer, transfer of an athlete, RFU regulations, KHL regulations.

Прежде всего, следует отметить, что рассматриваемые отношения относятся к сфере профессионального спорта, в связи с чем следует дать ему определение.

Федеральный закон от 04.12.2007 № 329-Ф3 «О физической культуре и спорте в Российской Федерации» даёт достаточно скудное понятие: «профессиональный спорт часть спорта, направленная на организацию и проведение профессиональных спортивных соревнований» [1]. Очевидно, что оно не отражает смысл и суть профессионального спорта, в связи с чем следует обратиться к определениям, данным в науке.

Л.А. Родионов понимает под профессиональным спортом «совокупность форм занятия спортом и соединенных с ними видов деятельности и общественных отношений (включая спортивные, спортивно-трудовые, предпринимательские, а также осуществляемые в спортивных организациях дисциплинарные и служебноиерархические отношения)» [8]. 
О.А. Шевченко предлагает следующее определение: «профессиональный спорт - это взаимодействующий комплекс общественных отношений, направленных на совершенствование спорта высших достижений, урегулированных международными актами, законодательством и иными нормативными правовыми актами, актами саморегулирования спортивных федераций (регламентами и правилами международных и национальных спортивных федераций, обычаями и принципами в сфере спорта), основанных на соглашении между субъектами в сфере профессионального спорта, направленных на систематическое участие в спортивных соревнованиях и подготовку к ним за определенное вознаграждение в целях реализации спортивного результата» [9]. Представляется, что данное определение является лучшим из представленных в науке, и позволяет определить систему правовых источников, регулирующих как профессиональный спорт, так и конкретно переход спортсменов из одного клуба в другой.

Таким образом, систему законодательства, регулирующего современные отношения по переходу спортсменов из одного клуба в другой в РФ составляет совокупность федеральных законов, специальных актов спортивных федераций и ассоциаций и лиг.

Следует отметить, что, законодательство о переходах спортсменов достаточно скудно и недостаточно, а системность не прослеживается. Рассматриваемые отношения в основном регулируются актами спортивных федераций и лиг.

Аналогичная позиция находит своё отражение в науке. К примеру Л. А. Родионова указывает, что: «среди огромного числа недостатков имеют место быть отсутствие соответствующей системности законодательства о спорте и надлежащей налаженности его внутренних связей, присутствие массы противоречащих и необъединенных едиными принципами правового регулирования законодательных и подзаконных нормативных правовых актов» [8]

Определяющим нормативно-правовым актом, регулирующим все отношения в области спорта в целом является Федеральный закон от 04.12.2007 № 329-Ф3 «О физической культуре и спорте в Российской Федерации» (далее - закон «О спорте»), который уже упоминался выше.

Стоит заметить, что переход спортсмена из одного клуба в другой включают 2 вида отношений: непосредственно отношения по переходу (трансферу) и сопутствующие им отношения между спортсменом и его агентом. В работе будут рассмотрены оба вида отношений.

Касаемо трансферных отношений, закон только лишь устанавливает право спортивных федераций на разработку и утверждение правил перехода, его ограничения и санкции за нарушения этих правил.

Министерством спорта утверждён Приказ от 13.12 .2019 № 1057 «Об утверждении перечня видов спорта, для которых общероссийские спортивные федерации по соответствующим виду или видам спорта вправе утверждать нормы, устанавливающие ограничения перехода (условия перехода) отдельных категорий спортсменов, тренеров в другие спортивные клубы или иные физкультурно-спортивные организации» [4]. Перечень содержит 137 различных видов спорта, в рамках данного исследования будут рассмотрены следующие виды спорта: футбол, хоккей.

Относительно агентских отношений закон устанавливает круг регулирующих актов: Закон «О спорте», иные нормативно правовые акты, нормы, утвержденные общероссийскими спортивными федерациями и профессиональными спортивными лигами.

Также закон устанавливает общие права и обязанности спортивных агентов, требования об их аккредитации.

При переходе спортсмена, клубы вступают в гражданские правоотношения, посредством заключения договора о переходе (трансферного контракта), в связи с чем 
можно говорить о том, что Гражданский кодекс РФ также будет входить в систему регулирующих рассматриваемые отношения нормативно-правовых актов.

Несмотря на то, что в Гражданском кодексе РФ отсутствуют какие-либо договоры, непосредственно регулирующие отношения, связанные с переходами спортсменов из одного клуба в другой, согласно принципу свободы договора, стороны вправе заключать непоименованные договоры, а также использовать нормы поименованных в ГК РФ договоров.

В зависимости от вида контракта и от его отнесения к тому или иному виду гражданско-правового договора, для регулирования отношений по трансферу можно использовать нормы договора купли-продажи, аренды, возмездного оказания услуг, мены. А для агентских отношений могут использоваться нормы об агентировании.

Далее следует перейти к рассмотрению специальных актов спортивных федераций и лиг.

В футболе, регулирующими международными актами являются Регламенты Международной федерации футбола (ФИФА) по статусу и трансферу игроков [10] и по работе с посредниками [11]. Внутрироссийские акты - Регламенты Российского футбольного союза (РФС) по статусу и переходу (трансферу) футболистов [7] и по работе с посредниками [6].

Главный международный акт, регулирующий трансферы футболистов Регламент ФИФА по статусу и трансферу игроков. Он устанавливает общеобязательные для всех футбольных федераций, входящих в ФИФА, правила, касающиеся статуса футболиста, их права участвовать в «организованном футболе» (то есть в рамках федерации, созданной под эгидой ФИФА) и трансферов между клубами различных ассоциаций (например между российским и зарубежным клубами).

Правила о переходах между клубами одной ассоциации устанавливаются непосредственно этой ассоциацией, о чём прямо указано в Регламенте ФИФА, и что мы видим на примере Регламента РФС. Связано это, конечно, с невозможностью создания аналогичного регулирования в разных странах, в связи с разностью правовых систем.

В общем виде данный регламент содержит нормы, относящиеся к трудовым договорам между футболистом и клубом, правила расчёта трансферной выплаты, регистрации футболиста в составе клуба, а также иные отношения, в работе не рассматривающиеся. В связи с этим можно переходить к рассмотрению Регламента РФС.

Данный регламент содержит не только правила, касающиеся статуса футболиста, трудового договора между футболистом и клубом, правила расчёта трансферной выплаты, регистрации футболиста, но и нормы о трансферном контракте и трансферном контракте на условиях «аренды», санкции за неисполнение контракта, что, собственно, и является предметом настоящего исследования.

Также Регламент содержит типовые формы названных выше контрактов.

Касаемо посредников, ФИФА также был принят соответствующий Регламент. Он регулирует отношения, связанные с привлечением игроками и клубами посредников для заключения трудового договора между игроком и клубом и заключения договора о переходе футболиста между двумя клубами.

Как указано в документе, ассоциации обязаны осуществлять и обеспечивать соблюдение, по крайней мере, установленных этим Регламентом минимальных стандартов (требований), с учетом национальных законодательных норм. Ассоциации должны разработать собственные правила, которые должны включать принципы, установленные в Регламенте ФИФА.

Регламент устанавливает ряд принципов. К примеру принцип должной осмотрительности при отборе посредников. Должная осмотрительность означает, что игроки и клубы должны прилагать разумные усилия для обеспечения того, чтобы 
посредники подписали соответствующую промежуточную декларацию, соблюдали её и договор о представительстве, заключенный между сторонами.

Документ вводит в отношения представительский договор, то есть договор между клубом/игроком и посредником о услугах, предоставляемых последним. Указаны форма договора и ряд существенных условий.

За ассоциациями сохраняется право выходить за рамки этих минимальных стандартов в собственных регламентах.

Вследствие этого Российским футбольным союзом был принят свой Регламент по работе с посредниками.

Предмет регулирования аналогичен международному регламенту, а именно участие посредников в отношениях между клубами, тренерами и футболистами при осуществлении трансферов из одного клуба в другой, а также в отношениях, связанных с трудовыми договорами.

Регламент устанавливает правила по аккредитации посредников, их права и обязанности, а также, конечно, нормы, связанные с договором с посредником.

В документе содержится типовая форма декларации посредника, но, в отличие от Регламента по трансферам, отсутствует типовая форма договора с посредником.

В связи с тем, что структура российского хоккея - калька с хоккея американского, то есть существует главная франшизная лига и лига уровнем ниже, смены команд между которыми по спортивному принципу не происходит, регулирование переходов спортсменов и агентских соглашений происходит не только на уровне регламентов общероссийской федерации, но и на уровне регламентов конкретных лиг (Континентальной Хоккейной Лиги (КХЛ) и Высшей Хоккейной Лиге (ВХЛ)).

Переходы хоккеистов в КХЛ регулируются главой 5 Правового регламента КХЛ «ПЕРЕХОДЫ» [3].

В отличие от футбола, Регламент КХЛ закрепляет четыре типа трансферов переход хоккеиста, переход хоккеиста со встречным переходом спортивных прав на другого хоккеиста, встречный переход и смешанный тип.

Обычный переход хоккеиста аналогичен футбольному трансферу. Переход хоккеиста со встречным переходом спортивных прав на другого хоккеиста означает, что встречным предложением будут спортивные права на хоккеиста, находящегося в различных нетипичных статусах. Встречный переход заключается в обмене равнозначного количества хоккеистов. Смешанный тип может включать несколько предыдущих типов одновременно.

Регламент содержит три вида типовых форм договоров о переходе (обмене) хоккеистов, применение которых зависит от ситуации при переходе.

В ВХЛ трансферы регулируются главой 24 «ПЕРЕВОД НА ДРУГУЮ РАБОТУ (ПЕРЕМЕЩЕНИЕ)» Регламента Высшей Хоккейной Лиги - Кубка Шелкового Пути (Всероссийского соревнования по хоккею среди мужских команд) [5].

В целом, Регламент ВХЛ содержит аналогичные Правовому регламенту КХЛ положения о переходах и типовые формы договоров.

Деятельность агентов в хоккее регулируется Положением о деятельности хоккейных агентов, утверждённым Федерацией хоккея России (ФХР) и КХЛ [2].

Положение определяет компетенцию и порядок работы Комиссии по аккредитации агентов, правила проведения аккредитации агентов, их права, обязанности и ответственность, порядок взаимодействия хоккеистов, тренеров и клубов с агентами, порядок разрешения споров, связанных с осуществлением агентской деятельности и, что самое важное требования к условиям и содержанию агентских договоров.

Таким образом, можно сделать следующие выводы. 
В общем виде системность нормативно-правовых актов, регулирующих современные отношения по переходу спортсменов из одного клуба в другой отсутствует.

Спортивное законодательство ни коим образом не регулирует рассматриваемые отношения, за исключением одной нормы, которая связывает федеральное законодательство с актами спортивных федераций и лиг и максимально общих правил об агентировании.

Гражданское законодательство может косвенно использоваться в зависимости от определения правовой природы используемых договоров, но прямое указание на это в законе отсутствует.

Более полно агентские отношения и отношения по трансферу регулируются регламентами спортивных федераций и лиг.

Таким образом, в футболе такими актами являются акты спортивных федераций Регламенты ФИФА по статусу и трансферу игроков и по работе с посредниками. А внутрироссийские акты - Регламенты РФС по статусу и переходу (трансферу) футболистов и по работе с посредниками.

Регламенты ФИФА устанавливают лишь общие правила регулирования, так как не могут учесть специфику национального законодательства, Регламенты РФС содержат конкретные нормы правового регулирования рассматриваемых отношений.

В хоккее, из-за его специфики, регламентирующими актами являются не только акты федераций, но и акты лиг. В КХЛ трансферные отношения регулирует Правовой регламент КХЛ, в ВХЛ Регламент Высшей Хоккейной Лиги. Деятельность агентов в хоккее регулируется Положением о деятельности хоккейных агентов.

Для приведения системы в удобоваримый вид можно использовать один, из следующих вариантов.

1. Переработать Федеральный закон «О спорте», включив в него общие нормы о трансферных контрактах.

2. Разработать специальный спортивный кодекс, в который включить главы о трансферах и агентах.

3. Не трогать Федеральный закон, а внести соответствующие нормы в виде отдельной главы или параграфов в Гражданский кодекс РФ.

Какой из вариантов наиболее предпочтителен, сказать сложно. Думается, что ответить на этот вопрос можно только после всестороннего обсуждения рассматриваемой проблемы учёными-юристами и практиками.

$$
* * *
$$

1. О физической культуре и спорте в Российской Федерации: федер. закон от 04.12.2007г. № 329-Ф3. [Электронный ресурс] СПС UКонсультант-плюс». URL: http://www.consultant.ru/document/cons_doc_LAW_73038/(дата обращения: 26.03.2021).

2. Положение о деятельности хоккейных агентов. (ред. от 23.04.2020) [Электронный ресурс] // Официальный сайт ФХР. - Режим доступа: https://fhr.ru/upload/iblock/d23/Polozhenie-o-deyatelnostikhokkei_nykh-agentov.pdf. (дата обращения: 26.03.2021).

3. Правовой регламент КХЛ (ред. от 09.10.2020) [Электронный ресурс] // Официальный сайт КХЛ. Режим доступа: https://www.khl.ru/documents/KHL_legal_regulations_2020.pdf. (дата обращения: 26.03.2021).

4. Приказ Минспорта России от 13.12.2019 № 1057 «Об утверждении перечня видов спорта, для которых общероссийские спортивные федерации по соответствующим виду или видам спорта вправе утверждать нормы, устанавливающие ограничения перехода (условия перехода) отдельных категорий спортсменов, тренеров в другие спортивные клубы или иные физкультурно-спортивные организации» (Зарегистрировано в Минюсте России 30.01.2020 N 57345) [Электронный ресурс] СПС «Консультант-плюс». URL: http://www.consultant.ru/document/cons_doc_LAW_344348/ (дата обращения: 26.03.2021).

5. Регламент Высшей Хоккейной Лиги - Кубка Шелкового Пути (Всероссийского соревнования по хоккею среди мужских команд) (ред. от 28.08.2020) [Электронный ресурс] // Официальный сайт 
ВХЛ. - Режим доступа: https://www.vhlru.ru/upload/Регламент\%20ВХЛ_КШП_20_21.pdf. (дата обращения: 26.03.2021).

6. Регламент РФС по работе с посредниками (ред. от 01.01.2021) [Электронный ресурс] // Официальный сайт РФС. - Режим доступа: https://static.rfs.ru/documents/1/5f7ade8b81861.pdf. (дата обращения: 28.12.2020).

7. Регламент РФС по статусу и переходам (трансферу) футболистов (ред. от 07.08.2020) [Электронный ресурс] // Официальный сайт РФС. - Режим доступа: https://static.rfs.ru/documents/1/5f329d11b8d4b.pdf. (дата обращения: 26.03.2021).

8. Родионов Л.А. Договорные формы правовых отношений в сфере профессионального спорта // Международный журнал гуманитарных и естественных наук. 2019. № 4-3. С. 184-187.

9. Шевченко, О. А. Правовая доктрина регулирования труда в сфере профессионального спорта и пути ее реализации в России: специальность 12.00 .05 «Трудовое право; право социального обеспечения»; дис. ... д-ра юрид. наук / О. А. Шевченко; «Московский государственный юридический университет имени О. Е. Кутафина (МГЮА). - М., 2014. 371 с.

10. Regulations on the Status and Transfer of Players January 2021 [Electronic resources] // Official site FIFA. - URL: https://resources.fifa.com/image/upload/regulations-on-the-status-and-transfer-of-playersjanuary-2021.pdf?cloudid=g1 ohngu7qdbxyo7kc38e (дата обращения: 26.03.2021).

11. Regulations on Working with Intermediaries [Electronic resources] // Official site FIFA. - URL: https://resources.fifa.com/image/upload/fifa-regulations-on-working-with-

intermediaries.pdf?cloudid=bntdqpzf9y8ntewsosb1 (дата обращения: 26.03.2021).

\section{Сергиенко А.А.}

\section{Понятие, признаки и пределы упрощения уголовно-процессуальной формы}

ФГБОУ ВО «Российский государственный университет правосудия» (Россия, Воронеж)

doi: 10.18411/lj-04-2021-250

\section{Аннотация}

В статье рассматриваются теоретические, законодательные и практические вопросы особого порядка принятия судебного решения при согласии обвиняемого с предъявленным ему обвинением. Анализируется законодательство, регламентирующее институт особого порядка судебного разбирательства при согласии лица с предъявленным ему обвинением.

Ключевые слова: особый порядок уголовного судопроизводства; обвиняемый; суд; согласие с обвинением; правосудие; уголовно-процессуальная форма.

\section{Abstract}

The article deals with the theoretical, legislative and practical issues of a special procedure for making a court decision with the consent of the accused with the charge brought against him. The article analyzes the legislation regulating the institution of a special procedure for judicial proceedings with the consent of a person with the charge brought against him.

Key words: special procedure of criminal proceedings; accused; court; consent to the prosecution; justice; criminal procedure form.

Анализ действующего уголовно-процессуального закона позволяет утверждать, что дифференциация российского уголовного процесса de lege lata уже имеет место, что является базой для определенного ускоренного производства по некоторым категориям уголовных дел. Проблема упрощения уголовного процесса пока еще не получила, на наш взгляд, адекватного доктринального толкования, хотя в специальных исследованиях все чаще поднимается вопрос об упрощенных судебных производствах, заочном рассмотрении уголовных дел, применении примирительных процедур как альтернативы уголовному преследованию. [1] Однако в условиях конвергенции процессуальных форм, имеющей место в мировой практике судопроизводства и лежащей в основе некоторых российских процессуальных процедур, например, особого 